whether it was named PE Corporation, Applied Biosystems, Applera, or Genes-RUs. Duarte promotes a companyPerkinElmer-as an investment for reasons that are completely false.

There is no defense for an error so fundamental whether you are a short-term trader or long-term investor, and it is not the only one in the book. A typical drive-by occurs when Duarte asserts that genomicsbased drug developer hopeful Human Genome Sciences had entered a drug into phase 3 clinical trials. Although this is a pivotal event for any investment analysis of a drug company, it is an imperative for one with no drugs on the market. Duarte is wrong: the company has several drug candidates in phase 2 and the cash to advance them, but none has ever entered phase 3 . This information is easily available. There are dozens more errors like this.

\section{What you should do}

The vast majority of investors belong in a low-expense broad-market stock index fund, such as one that tracks the S\&P 500 Index. Your employer may have one in the 401(k) plan (if not, lobby for it). But if you really want to apply your professional knowledge to investing, do not put a dime into a company that uses biotechnology to revolutionize medicine until you have read enough to have a healthy respect for the significant risks.

Three books that will be on the exam for Biotech Investing 101 (the Motley Fool's training ground for biotech investors) are Cynthia Robbins-Roth's From Alchemy to IPO: The Business of Biotechnology (Perseus, 2000), Barry Werth's gripper, The Billion-Dollar Molecule, One Company's Quest for the Perfect Drug (Touchstone, 1995), and John Perry's How to Read a Financial Report (Edn. 4, Wiley, 1994). Robbins-Roth, a PhD scientist, left Genentech for a career in biotechnology consulting, and her book sports the best history of modern biotechnology I have read (for a review, see Nat. Biotechnol. 18, $799,2000)$. Werth penned a riveting account of the blood, sweat, tears, and money expended in drug making, and Perry's book is a most friendly introduction to The Numbers.

\section{Start your calculators}

About those numbers. There is absolutely no shortcut to anything that matters, and that's as true of your $\mathrm{PhD}$ in genetics as investing. Over the long term-say, five years and longer-the stock prices of businesses rise and fall on evaluations of their ability to generate future cash in excess of expenses. Period. End of story. The only way that you can evaluate this is to arm yourself with the information provided in company financial statements. If you have no time or interest to learn about the numbers, and persist in investing in companies whose technology is all you understand, you will be beaten over the head-or wallet-again and again. Perry's book is the place to start.

To expand your general investing knowledge, try any book by Peter Lynch or about Warren Buffett's investing strategy. And to learn that you can invest in stocks with even a little amount of money, read my Motley Fool colleague and friend Jeff Fischer's Investing Without a Silver Spoon (Motley Fool, 1999).

\section{Prefer gardening?}

Don't want to learn the numbers? Prefer to spend your time sequencing your genome, enjoying your loved ones, and growing roses? Then stick with that low-expense, broad-market stock index fund, and sleep soundly at night. Skip the biotechnology sector mutual funds, which pay handsome fees to managers to trade your stocks-an average $100 \%$ turnover a year in the average stock fund, according to Morningstar. Even a so-called biotechnology sector index fund is no easy way out: index or no, all biotechnology funds indiscriminately lump good businesses in with the bad. This may benefit mutual funds' marketing departments, but it is unlikely to bring you returns that outperform the market averages.

There is no easy route to money in the stock market, biotechnology or anything else. Investing is simple-a calculator, interest, and time are all you need-but it is not easy. Duarte's book, like many others that feed the financial publishing industry's hungry maw, is no shortcut, and it could cause you great harm.

\section{Erratum}

On p. 812 of the September issue, Junko Yasufuku-Takano, a coauthor who greatly contributed to the study reported in the letter entitled "Estrogenic impurities in labware", was omitted from the list of authors. Her name should have been printed between "Koji Takano" and "Toshiro Fujita". In the same letter, Table 1 also contains an error. CellStar is a brand manufactured by Greiner, not Corning.

On p. 1027 of the November issue, the Research News Brief entitled "Antisense targets pathogens" contained incorrect citation details for the paper described. The correct citation is Science 293, 2266-2269, 2001. 